\title{
Effects of dietary methionine on productivity, reproductive performance, antioxidant capacity, ovalbumin and antioxidant-related gene expression in laying duck breeders
}

\author{
Dong Ruan ${ }^{1,2}$, Ahmed Mohamed Fouad ${ }^{1,3}$, Qiuli Fan ${ }^{1}$, Weiguang Xia ${ }^{1}$, Shuang Wang ${ }^{1}$, Wei Chen ${ }^{1}$, \\ Chuxiao Lin ${ }^{1}$, Ying Wang ${ }^{1}$, Lin Yang ${ }^{2 *}$ and Chuntian Zheng ${ }^{1 *}$ \\ ${ }^{1}$ Key Laboratory of Animal Nutrition and Feed Science (South China) of Ministry of Agriculture, State Key Laboratory \\ of Livestock and Poultry Breeding, Guangdong Public Laboratory of Animal Breeding and Nutrition, Guangdong Key \\ Laboratory of Animal Breeding and Nutrition, Institute of Animal Science, Guangdong Academy of Agricultural Sciences, \\ Guangzhou 510640, People's Republic of China \\ ${ }^{2}$ College of Animal Science, South China Agricultural University, Guangzhou 510640, People's Republic of China \\ ${ }^{3}$ Department of Animal Production, Faculty of Agriculture, Cairo University, Giza 12613, Egypt \\ (Submitted 24 May 2017 - Final revision received 12 October 2017 - Accepted 6 November 2017 - First published online 26 December 2017)
}

\section{Abstract}

The study investigated whether dietary methionine (Met) affects egg weight and antioxidant status through regulating gene expression of ovalbumin $(O V A L)$, nuclear factor erythroid 2 like $2(N r f)$ and haem oxygenase $1(H O-1)$ in laying duck breeders. Longyan duck breeders ( $n$ 540,19 weeks) were randomly assigned to six treatments with six replicates of fifteen birds each. Breeders were fed diets with six Met levels $(2 \cdot 00,2 \cdot 75,3 \cdot 50,4 \cdot 25,5 \cdot 00$ and $5 \cdot 75 \mathrm{~g} / \mathrm{kg})$ for 24 weeks. The egg weight $(\mathrm{g})$, egg mass $(\mathrm{g} / \mathrm{d})$, feed conversion ratio, hatchability, $1-\mathrm{d}$ duckling weight, albumen weight, albumen proportion and $O V A L$ mRNA level improved with dietary Met levels, whereas yolk proportion decreased $(P<0.05)$. The weight of total large yellow follicles increased linearly $(P<0.001)$ and quadratically $(P<0.05)$ with dietary Met concentration, and their weight relative to ovarian weight showed a linear $(P<0.05)$ effect. Dietary Met level had a linear $(P<0.05)$ and quadratic $(P<0 \cdot 001)$ effect on the gene expression of glutathione peroxidase (GPX1), HO-1 and $N r f 2$, and quadratically $(P<0 \cdot 05)$ increased contents of GPX and total antioxidant capacity (T-AOC) in liver of duck breeders. In addition, maternal dietary Met enhanced gene expression of GPX1, HO-1 and $N r f 2$, increased contents of GPX and T-AOC and reduced carbonylated protein in the brains of hatchlings. Overall, dietary Met concentration affected egg weight and albumen weight in laying duck breeders, which was partly due to gene expression of $O V A L$ in oviduct magnum. A diet containing $4.0 \mathrm{~g}$ Met $/ \mathrm{kg}$ would achieve optimal hepatic GPX1 and $N r f 2$ expression, maximise the activity of GPX and minimise lipid peroxidation.

Key words: Methionine: Antioxidant capacity: Ovalbumin: Performances: Laying duck breeders

Methionine (Met) is considered to be the highest priority amino acid in poultry diets as it is the first limiting amino acid and has multiple biological functions in avian species $^{(1)}$. Dietary Met levels affect the secretion of hormones in animals, such as triiodothyronine, insulin growth factor-II, estradiol, folliclestimulating hormone and luteinising hormone ${ }^{(2-4)}$. In avian species, Met deficiency impairs the laying performance, egg mass, feed conversion ratio $(\mathrm{FCR})^{(5-7)}$, antibody production ${ }^{(8)}$ and retards female reproductive organ development ${ }^{(9-11)}$, including relative weight of the ovary, oviduct length, total number of follicles, large and small, and the growth rate of secondary follicles ${ }^{(4)}$. Met deficiency can lead to imbalanced lipid and protein metabolism, which reduces egg quality and increases the incidence of reproductive problems associated with fatty liver and obesity ${ }^{(10-13)}$. The Met is involved in the biosynthesis of GSH, cysteine, taurine and carnitine ${ }^{(14)}$, which play vital roles as antioxidants ${ }^{(15-17)}$. Several studies have reported that dietary Met supplementation increased the content of cysteine, taurine and the activities of antioxidant enzymes, and reduced the lipid peroxidation in Chinese broiler breeders and commercial broiler chickens ${ }^{(5,18)}$. However, it was reported that dietary Met levels ranging from 2.5 to $5.0 \mathrm{~g} / \mathrm{kg}$ did

Abbreviations: cDNA, complementary DNA; FCR, feed conversion ratio; GPX, glutathione peroxidase; HO-1, haem oxygenase 1; LYF, large yellow follicles; MDA, malondialdehyde; Met, methionine; Nrf2, nuclear factor erythroid 2 like 2; OVAL, ovalbumin; SYF, small yellow follicles; T-AOC, total antioxidant capacity; T-SOD, total superoxide dismutase.

* Corresponding authors: C. Zheng, fax +8620 61368880, email zhengcht@163.com; L. Yang, email ylin898@126.com 
not affect the plasma glutathione redox system in laying ducks, which was possibly due to not low enough Met level in the basal $\operatorname{diet}^{(7)}$. In this regard, it was hypothesised that a control diet containing less Met $(2.0 \mathrm{~g} v .2 .5 \mathrm{Met} / \mathrm{kg})$ might affect the activities of antioxidant enzymes and their mRNA expression levels in duck breeders and their offspring by modulating the expression of nuclear factor erythroid 2 like 2 (Nrf2), but this has not been investigated previously. Moreover, previous reports have shown that dietary Met levels increases the egg weight and albumen secretion in different strains of laying ducks and laying hens, which was reflected in egg weight ${ }^{(3,6,7)}$, but the relationship between them was little referred. Thus, it might be possible that dietary Met can induce the same effect in duck breeders as laying ducks, which may lead to an increase in the weight of hatchings, by altering gene expression of ovalbumin (OVAL, the dominant protein in albumen) in duck breeders.

In poultry, Met improves the productivity, reproductive performance, egg quality, antioxidant defence system and humoral and cellular immune responses, and attenuates the adverse impacts of non-optimal temperature (cold or heat stress $)^{(5,7,18,19)}$. Thus, the effects of Met on commercial and local strains of broiler breeders, laying hens, quails, turkeys, meat-type and egg-type ducks can be positive, but variable $^{(3,6,7,18,20,21)}$. Further, few studies have reported the effect of dietary Met levels in laying duck breeders. The Longyan duck breeders are the most popular laying ducks for duckling production in South China, mainly because of their high productivity, adaption to high ambient temperature and resistance to diseases. Therefore, the current study sought to determine the effect of dietary Met levels on productivity, reproductive performance, antioxidant capacity, OVAL and antioxidant-related gene expression in laying duck breeders; it also examined whether dietary Met increases the secretion of albumen by upregulating expression of the $O V A L$ gene in duck breeders and improving the activities of antioxidant enzymes and their gene expression levels in duck breeders and their offspring by modulating the expression of $N r f 2$.

\section{Methods}

\section{Birds, diets and experimental design}

All experimental procedures were approved by the Animal Care and Use Committee of Guangdong Academy of Agriculture Sciences, China. A total of 540 female Longyan laying duck breeders with the same genetic background in terms of the parental generation and with comparable body weight (BW) at 19 weeks of age were randomly assigned to six dietary treatments, each comprising six replicates of fifteen birds. The ducks were individually housed in galvanised steel battery cages (length $42 \mathrm{~cm} \times$ width $30 \mathrm{~cm} \times$ height $50 \mathrm{~cm}$; Guangzhou Huanan Poultry Equipment Co., Ltd) with a nipple drinker and feeder; the ambient temperature varied from 15 to $32^{\circ} \mathrm{C}$ during the 24-week experimental period. Fresh drinking water was available ad libitum, and $80 \mathrm{~g}$ of feed per duck in pellet form was introduced twice daily at 07.00 and 15.00 hours. A $16 \mathrm{~h}$ light-8h dark photoperiod was applied throughout the study.
The basal diet (Table 1) was formulated to satisfy the nutritional requirements for Longyan laying duck breeders with the exception of Met. The six groups were fed the basal diet supplemented with 0 (control), $0 \cdot 75,1 \cdot 50,2 \cdot 25,3.00$ or $3.75 \mathrm{~g}$ $\mathrm{Met} / \mathrm{kg}$ in the form of DL-Met (MetAMINO ${ }^{\circledR}$; Evonik Industries AG), respectively, which resulted in total contents of $2 \cdot 00,2 \cdot 75$, $3 \cdot 50,4 \cdot 25,5.00$ and $5.75 \mathrm{~g} / \mathrm{kg}$. Male Longyan duck breeders were fed a standard commercial diet containing $10 \cdot 87 \mathrm{MJ} / \mathrm{kg}$ metabolisable energy $/ \mathrm{kg}, 170 \mathrm{~g} / \mathrm{kg}$ crude protein, $8.00 \mathrm{~g} / \mathrm{kg} \mathrm{Ca}$, $3 \cdot 80 \mathrm{~g} / \mathrm{kg}$ available phosphorus and $4.50 \mathrm{~g} / \mathrm{kg}$ Met. At 38 weeks of age, each breeder was artificially inseminated twice weekly with $100 \mu \mathrm{l}$ of pooled semen ${ }^{(22)}$ to evaluate reproductive performance (fertility, hatchability and proportion of healthy ducklings). In total, 1800 eggs (fifty eggs from each replicate) were collected over 5 sequential days between 38 and 39 weeks from the 2nd day after the first artificial insemination, the eggs were weighed, labelled and stored in a dark controlledtemperature room $\left(18^{\circ} \mathrm{C}\right.$ and 75 to $80 \%$ relative humidity), and then incubated in the incubator (JXB2000; Dezhou Jingxiang Technology Co., Ltd) for $28 \mathrm{~d}$. On the first $5 \mathrm{~d}$, the incubator temperature was $38.4^{\circ} \mathrm{C}$ with $45 \%$ humidity; from 6 to $10 \mathrm{~d}$, the temperature was $38.0^{\circ} \mathrm{C}$ with $50 \%$ humidity; from 11 to $15 \mathrm{~d}$, the temperature was $37.5^{\circ} \mathrm{C}$ with $50 \%$ humidity; from 16 to $20 \mathrm{~d}$, the temperature was $37 \cdot 1^{\circ} \mathrm{C}$ with $55 \%$ humidity; from 21 to $25 \mathrm{~d}$, the temperature was $36 \cdot 8^{\circ} \mathrm{C}$ with $60 \%$ humidity; and from 26 to $28 \mathrm{~d}$, the temperature was $36.5^{\circ} \mathrm{C}$ with $65 \%$ humidity. The eggs were candled on days 6 and 18 to eliminate infertile eggs and dead embryos. The fertility and hatchability were

Table 1. Ingredients and nutrient composition of the basal diet for laying duck breeders, as-fed basis

\begin{tabular}{|c|c|}
\hline Items & Basal diet \\
\hline \multicolumn{2}{|l|}{ Ingredients (g/kg) } \\
\hline Maize & $360 \cdot 0$ \\
\hline Mazie starch & $168 \cdot 0$ \\
\hline Wheat bran & $100 \cdot 0$ \\
\hline Soyabean meal & $100 \cdot 0$ \\
\hline Peanut meal & $160 \cdot 0$ \\
\hline L-Lys, HCl (98.5\%) & $2 \cdot 2$ \\
\hline DL-Met $(99 \%)$ & 0.0 \\
\hline Limestone & $84 \cdot 8$ \\
\hline Calcium hydrogen phosphate & $12 \cdot 0$ \\
\hline Sodium chloride & 3.0 \\
\hline Vitamin and trace-mineral premix ${ }^{*}$ & $10 \cdot 0$ \\
\hline Total & $1000 \cdot 0$ \\
\hline \multicolumn{2}{|l|}{ Nutrient composition (g/kg) } \\
\hline Metabolisable energy (MJ/kg) & $10 \cdot 46$ \\
\hline Crude protein† & $171 \cdot 7$ \\
\hline $\mathrm{Ca}$ & $36 \cdot 0$ \\
\hline Total P & $5 \cdot 6$ \\
\hline Non-phytate P & 3.5 \\
\hline Lys & $8 \cdot 5$ \\
\hline Met† & $2 \cdot 1$ \\
\hline Met + Cys & $5 \cdot 6$ \\
\hline \multicolumn{2}{|c|}{$\begin{array}{l}\text { * The premix provided per kilogram diet: vitamin } A, 3.96 \mathrm{mg} \text {; vitamin } D_{3}, 0.066 \mathrm{mg} \text {; } \\
\text { vitamin } \mathrm{E}, 20 \mathrm{mg} \text {; vitamin } \mathrm{K}_{3}, 2.75 \mathrm{mg} \text {; vitamin } \mathrm{B}_{1}, 4.4 \mathrm{mg} \text {; vitamin } \mathrm{B}_{2}, 9.0 \mathrm{mg} \text {; } \\
\text { vitamin } \mathrm{B}_{6}, 4.4 \mathrm{mg} \text {; vitamin } \mathrm{B}_{12}, 0.02 \mathrm{mg} \text {; choline, } 500 \mathrm{mg} \text {; nicotinic acid, } 30 \mathrm{mg} \text {; } \\
\text { pantothenic acid, } 22 \mathrm{mg} \text {; folic acid, } 1.1 \mathrm{mg} \text {; biotin, } 0.22 \mathrm{mg} \text {; Fe from ferrous } \\
\text { sulphate, } 60 \mathrm{mg} \text {; Cu from copper sulphate, } 8.0 \mathrm{mg} \text {; Mn from manganese oxide, } \\
100 \mathrm{mg} \text {; } \mathrm{Zn} \text { from zinc oxide, } 90 \mathrm{mg} \text {; iodine from ethylenediamine dihydroidide, } \\
0.5 \mathrm{mg} \text {; Se from sodium selenite, } 0.2 \mathrm{mg} \text {; Co from cobaltous sulphate, } 0.26 \mathrm{mg} \text {. } \\
\text { † Measured values of crude protein and methionine content. Each value is based on } \\
\text { triplicate determinations. Other nutrient compositions are calculated values. }\end{array}$} \\
\hline
\end{tabular}


determined along with hatchling weights of ducklings being recorded on the hatching day.

\section{Sample collection}

At the end of the experiment (after feeding for 24 weeks), twelve breeders per treatment were selected at random (excluding obvious outliers in terms of BW, two breeders in each replicate) for sampling. Heparinised blood was collected from the wing vein, centrifuged at $1000 \mathrm{~g}$ for $20 \mathrm{~min}$ at $4^{\circ} \mathrm{C}$ and the plasma was then collected and stored at $-20^{\circ} \mathrm{C}$ until further analysis. The breeders were then stunned, exsanguinated and the ovaries were collected and weighed. Samples were collected from the liver, oviduct magnum and ovaries $^{(23,24)}$, which were rinsed rapidly with PBS, snap-frozen in liquid $\mathrm{N}_{2}$ and stored at $-80^{\circ} \mathrm{C}$. After hatching, twelve ducklings from each treatment group (two ducklings from each replicate) were stunned, exsanguinated and samples of the liver and brain ${ }^{(25)}$ were harvested, rinsed quickly with PBS, snapfrozen in liquid $\mathrm{N}_{2}$ and stored at $-80^{\circ} \mathrm{C}$.

\section{Determination of productive and reproductive performance}

The feed intake was recorded daily on a per replicate basis. The numbers of total, broken and shell-less eggs were recorded daily by replicate. The eggs produced were individually weighed and graded daily. Egg production (\%) $(100 \times$ number of eggs/number of breeders), egg weight (g), egg mass (g/d), average daily feed intake and FCR ( $g$ feed/g egg) were calculated daily, on a per replicate basis, and the data were then pooled before analysis. The fertility and hatchability were also calculated, and the proportion of healthy ducklings was calculated as the number that were clean, dry, free of deformities and with bright eyes, as described by Tona et al. ${ }^{(26)}$, expressed as a percentage relative to the total number of hatchlings.

\section{Egg quality}

At the end of the experiment, four eggs were collected at random (excluding obvious outliers such as excessively large or small, rough, misshapen, cracked) from each replicate, and the average of these twenty-four eggs was calculated per treatment to determine the quality traits. Yolk colour score, albumen height and Haugh unit (albumen quality) were measured on the day of collection using an Egg Analyzer (model EA-01; ORKA Food Technology). The strength of the shell was determined on the vertical axis using an Egg Force Reader (model EFR-01; ORKA Food Technology). Eggshell thickness was measured using a digital micrometre, and egg shape index (SI) was determined with a digital caliper and calculated as $\mathrm{SI}=$ width $\times 100 /$ length, where the length was the distance between the blunt and pointed ends and the width was the diameter at the mid-length. The eggs were weighed, and then the yolks were separated, weighed and expressed as percentages of egg weight. The shells with membranes were weighed after drying at $105^{\circ} \mathrm{C}$ and expressed as percentages of egg weight. Finally, the albumen weight was calculated as egg weight minus the weight of yolk and eggshell, and expressed as percentages of egg weight.

\section{Ovary and oviduct-related indices}

The collected ovaries, small yellow follicles (SYF; $3 \mathrm{~mm}<$ diameter $<8 \mathrm{~mm}$ ), large yellow follicles (LYF; diameter $\geq 8 \mathrm{~mm}$ ) and oviduct were weighed using an electronic balance (AB-S/PH; Mettler Toledo). The numbers of total SYF and LYF were recorded. The weights of total SYF and LYF were calculated relative to the ovarian weight and expressed as ratios.

\section{Biochemical assay of plasma and tissue samples}

The plasma contents of GSH and malondialdehyde (MDA), activities of total superoxide dismutase (T-SOD) and glutathione peroxidase (GPX), and the total antioxidant capacity (T-AOC) were determined in duplicate colourimetrically using commercial kits according to the manufacturer's protocols (Jiancheng Bioengineering Institute), similar to that described by Huang et al. ${ }^{(27)}$.

A quantity of $40 \mathrm{mg}$ of frozen liver or brain were homogenised on ice in $4 \mathrm{ml}$ of homogenisation buffer $(0.05 \mathrm{M}$ TRIS-HCl, pH 7.4, $1 \mathrm{~mm}$ EDTA, 0.25 $\mathrm{m}$ sucrose) with an UltraTurrax (T8; IKA) for $5 \mathrm{~s}$ at $3000 \mathrm{~g}$. The homogenate was centrifuged at $12000 \mathrm{~g}$ for $10 \mathrm{~min}$ at $4{ }^{\circ} \mathrm{C}$, and the supernatant was stored at $-80^{\circ} \mathrm{C}$. The concentrations of GSH, MDA and activities of T-SOD, GPX and T-AOC in the livers of breeders, as well as in the livers and brains of ducklings, were measured with kits (Jiancheng Bioengineering Institute). The concentrations of protein carbonyl (PC) in the brains of ducklings were measured with kits (Jiancheng Bioengineering Institute), similar to that described by Huang et $a l .{ }^{(27)}$. All samples were measured in duplicate at appropriate dilutions in order to determine the concentrations of GSH, MDA, PC and activities of the enzymes in the linear range for standard curves constructed with pure enzymes. The protein contents of supernatants were determined using Coomassie Brilliant Blue G250 (Sigma Chemical) with bovine serum albumin as the standard.

\section{Total RNA extraction and reverse transcription}

Total RNA was extracted from the frozen tissues using TRIzol $^{\circledR}$ (Invitrogen) and treated with DNase (Takara) according to the manufacturers' protocols. RNA concentrations were determined by NanoDrop 1000 (ThermoFisher Scientific) and RNA integrity was verified by electrophoresis on $1 \%$ agarose gels.

Total RNA $(2.5 \mu \mathrm{g})$ from each sample was used to generate complementary DNA (cDNA) in a final volume of $20 \mu \mathrm{L}$ according to the manufacturer's instructions (Promega). The cDNA was then diluted 1:10 with nuclease-free water (Ambion) and stored at $-20^{\circ} \mathrm{C}$ until use. Primers for the genes of interest were designed with Primer Premier 5.0 based on duck sequences in GenBank, as shown in Table 2; they were obtained from Shanghai ShengGong Biological Company. The cDNA was amplified by PCR under the optimal conditions, which consisted of an initial 5-min denaturation at $95^{\circ} \mathrm{C}$; thirtyfive cycles of $30 \mathrm{~s}$ at $95^{\circ} \mathrm{C}, 30 \mathrm{~s}$ at the annealing temperature (Ta) and extension for $30 \mathrm{~s}$ at $72^{\circ} \mathrm{C}$; and a final extension at $72^{\circ} \mathrm{C}$ for $10 \mathrm{~min}$. Aliquots of PCR products were evaluated by electrophoresis in $1.5 \%$ agarose gels and excised products from the gels were sequenced to verify authenticity. 
Table 2. Primer sequences used for quantitative real-time PCR

\begin{tabular}{|c|c|c|c|c|}
\hline Genes & Primer sequence $\left(5^{\prime}-3^{\prime}\right)$ & Accession no. & Amplicon (bp) & $\mathrm{Ta}\left({ }^{\circ} \mathrm{C}\right)$ \\
\hline$S O D 1$ & $\begin{array}{l}\text { F: CCTGTGGTGTCATCGGAATA } \\
\text { R: TTGAACGAGGAAGAGCAAGTA }\end{array}$ & XM_013097859.1 & 116 & 57 \\
\hline$G P X 1$ & $\begin{array}{l}\text { F: CAGTACATCATCTGGTCGCC } \\
\text { R: CCTGGATCTTGATGGTTTCG }\end{array}$ & KU048803.1 & 127 & 57 \\
\hline$C A T$ & $\begin{array}{l}\text { F: CTGTTGAGGAAGCAGGAAGG } \\
\text { R: GAAAGACCAGGATGGGTAGTTG }\end{array}$ & KU048802.1 & 101 & 57 \\
\hline $\mathrm{HO}-1$ & $\begin{array}{l}\text { F: CCCATGCCTACACTCGCTAT } \\
\text { R: GCCTCCTCCAAGACTCGTTT }\end{array}$ & KU048806.1 & 217 & 57 \\
\hline Nrf2 & $\begin{array}{l}\text { F: GTTGAATCATCTGCCTGTGG } \\
\text { R: TAAGCTAGGTGGTCGAGTGC }\end{array}$ & NM_001310777.1 & 171 & 57 \\
\hline OVAL & $\begin{array}{l}\text { F: CCTGGTTAATGCCATTTACTTC } \\
\text { R: CTGGTACATCATCTGGACGG }\end{array}$ & NM_001311169.1 & 121 & 57 \\
\hline$\beta$-Actin & $\begin{array}{l}\text { F: GCTATGTCGCCCTGGATTT } \\
\text { R: GGATGCCACAGGACTCCATAC }\end{array}$ & EF667345.1 & 174 & 60 \\
\hline
\end{tabular}

$\mathrm{Ta}$, annealing temperature; SOD1, superoxide dismutase 1; GPX1, glutathione peroxidase 1; CAT, catalase; HO-1, haem oxygenase 1; Nrf2, nuclear factor erythroid 2 like 2; OVAL, ovalbumin.

\section{Quantitative real-time $P C R$ analysis}

Quantitative real-time PCR was performed using the same primers to quantify mRNA contents. Each $20 \mu$ PCR mixture contained $10 \mu \mathrm{l}$ of $2 \mathrm{X}$ iQTM SYBR Green Supermix, $0 \cdot 8 \mu \mathrm{l}$ ( $10 \mathrm{~mm}$ ) of each primer and $2 \mu \mathrm{l}$ of cDNA. The mixtures were incubated using an iCycler iQ Real-time Detection system (Bio-Rad) for thirty-nine cycles $\left(95^{\circ} \mathrm{C}\right.$ for $15 \mathrm{~s}$ and at the Ta for $30 \mathrm{~s}$ ). Quantification of the transcripts was performed using a standard curve with 10-fold serial dilutions of cDNA. A melting curve was constructed to verify that only a single PCR product was amplified. Samples were assayed in triplicate with standard deviations of threshold cycle $\left(C_{t}\right)$ values not exceeding $0 \cdot 5$. The $2^{-\Delta \Delta C_{t}}$ method was used with $\beta$-actin as the reference transcript for relative gene expression and then expressed relative to the transcript abundance in birds fed the control diet ${ }^{(28)}$.

\section{Statistical analysis}

Replicate ( $n$ 6) served as the experimental unit, where two breeders and ducklings were sampled per replicate unless stated otherwise. The experimental data were analysed by one-way ANOVA using the general linear model procedure in SAS (version 9.2; SAS Institute Inc.). Differences between means were assessed using Duncan's multiple range tests at $P<0.05$ probability level. Results are expressed as means with their standard errors, derived from the ANOVA error mean square. Only when the main effect was shown to be significant $(P<0.05)$, orthogonal comparisons were used to estimate the linear and quadratic effects of Met supplementation. Quadratic regressions $\left(Y=c+b X+a X^{2}\right)$ were fitted to the responses of the dependent variables to Met supplementation. The dietary concentration of Met at which the response first reached $95 \%$ of the maximum was used to estimate the requirement ${ }^{(29)}$.

The sample size $(n)$ was estimated using the following equation: $n=\psi^{2}\left(\sum\left(S_{i}^{2}\right) / K\right) /\left[\sum\left(X_{i \text { average }}-X_{\text {average }}\right)^{2} /(K-1)\right]^{(30)}$, where $n$ is the sample size, $\Psi$ is $\psi$ value, $K$ is the group count, $\alpha$ is the probability of a type I error occurring at $5 \%, \beta$ is the probability of a type II error occurring at $10 \%, S_{i}$ and $X_{i}$ average are the standard deviation and the average value of corresponding $i$ th group, respectively. For example, for the most variable index, $\Psi=3 \cdot 08$, $\alpha=0.05, \beta=0 \cdot 10, X_{\text {average }}=2.00$ and the sample size needed to detect a significant main effect between groups was at least $n 6$ ducks per group.

\section{Results}

\section{Productive and reproductive performance}

Dietary Met significantly affected $(P<0 \cdot 05)$ the egg weight, egg mass, FCR, hatchability, healthy ducklings and weight of hatchlings (Table 3 ). The egg weight and $1 \mathrm{~d}$ duckling weight increased in a linear $(P<0.001)$ manner, with a lesser quadratic $(P<0.05)$ component as Met concentration increased. The egg mass increased, and then decreased quadratically $(P<0.05)$ as dietary Met concentration increased. The hatchability and proportion of healthy ducklings increased in a linear $(P<0.05)$ and quadratic $(P<0.05)$ manner as Met concentration increased. There were no significant effects $(P>0.05)$ of dietary Met levels on daily egg production and fertility.

\section{Egg quality}

Among the egg quality indices (Table 4), the albumen weight, albumen proportion and Haugh unit increased in a linear $(P<0.05)$ and quadratic $(P<0.05)$ manner with dietary Met concentration, whereas the yolk proportion decreased in a linear $(P<0.001)$ and quadratic $(P<0.05)$ manner. There were no significant effects $(P>0.05)$ of increasing Met on the eggshell thickness, egg SI, eggshell strength, yolk colour and eggshell weight and proportion.

\section{Ovary and oviduct-related indices}

As shown in Table 5, the weight of total LYF increased linearly $(P<0.001)$ with a minor quadratic effect $(P<0.05)$, and the ratio of total LYF weight/ovarian weight was also affected in a linear $(P=0.002)$ manner by dietary Met concentration. The 
Table 3. Effects of the dietary methionine (Met) level on the productivity (19-43 weeks) and reproductive performance (38-39 weeks) of duck breeders in the peak laying period

(Mean values with their standard errors, $n 6$ )

\begin{tabular}{|c|c|c|c|c|c|c|c|c|}
\hline $\begin{array}{l}\text { Dietary Met } \\
(\mathrm{g} / \mathrm{kg})\end{array}$ & EP (\%) & $\mathrm{EW}(\mathrm{g})$ & $\operatorname{EM}(\mathrm{g} / \mathrm{d})$ & FCR $(g: g)$ & Fertility (\%) & Hatchability (\%) & Healthy duckling (\%) & 1-d duckling BW (g) \\
\hline 2.00 & 82.03 & $56 \cdot 73^{\mathrm{c}}$ & $46 \cdot 25^{\mathrm{b}}$ & $3.58^{\mathrm{a}}$ & 89.47 & $69 \cdot 89^{b}$ & $94.51^{a, b}$ & $31 \cdot 71^{c}$ \\
\hline 2.75 & 80.95 & $61 \cdot 23^{\mathrm{b}}$ & $49.57^{\mathrm{b}}$ & $3.53^{a, b}$ & $85 \cdot 29$ & $78.56^{b}$ & $97 \cdot 85^{a}$ & $33.58^{b}$ \\
\hline 3.50 & 81.36 & $62 \cdot 12^{\mathrm{a}, \mathrm{b}}$ & $51.66^{\mathrm{b}}$ & $3 \cdot 42^{a, b}$ & $90 \cdot 85$ & $84.67^{a}$ & $98 \cdot 19^{a}$ & $34.67^{\mathrm{a}, \mathrm{b}}$ \\
\hline 4.25 & 82.59 & $63.58^{\mathrm{a}}$ & $52 \cdot 77^{\mathrm{a}}$ & $3 \cdot 25^{\mathrm{C}}$ & 90.96 & $87 \cdot 20^{\mathrm{a}}$ & $97.91^{\mathrm{a}}$ & $35.08^{a, b}$ \\
\hline 5.00 & 81.84 & $64 \cdot 12^{\mathrm{a}}$ & $52 \cdot 24^{a}$ & $3 \cdot 31^{\mathrm{bc}}$ & 92.08 & $86 \cdot 31^{a}$ & $99.52^{a}$ & $36 \cdot 18^{a}$ \\
\hline 5.75 & 81.75 & $63.45^{a}$ & $52.03^{c}$ & $3 \cdot 34^{b, c}$ & 89.47 & $81 \cdot 29^{a, b}$ & $92.04^{b}$ & $35 \cdot 61^{a, b}$ \\
\hline $\begin{array}{l}\text { SEM } \\
P\end{array}$ & $2 \cdot 322$ & 0.683 & 0.842 & 0.061 & 1.598 & 1.562 & 0.638 & 0.331 \\
\hline Met & 0.193 & $<0.001$ & 0.011 & 0.022 & 0.303 & 0.041 & 0.022 & $<0.001$ \\
\hline Linear & & $<0.001$ & 0.123 & 0.224 & & 0.014 & 0.048 & $<0.001$ \\
\hline Quadratic & & 0.032 & 0.043 & 0.042 & & 0.013 & 0.021 & 0.024 \\
\hline
\end{tabular}

EP, egg production; EW, egg weight; EM, egg mass; FCR, feed conversion ratio; BW, body weight.

a,b,c Mean values within a column with unlike superscript letters were significantly different $(P<0.05)$.

Table 4. Effects of the dietary methionine (Met) level on the egg composition and quality of duck breeders during the laying period from 19 to 43 weeks of age

(Mean values with their standard errors, $n 6$ )

\begin{tabular}{|c|c|c|c|c|c|c|c|c|c|c|c|c|}
\hline $\begin{array}{l}\text { Dietary } \\
\text { Met }(\mathrm{g} / \mathrm{kg})\end{array}$ & $\begin{array}{c}\text { Egg } \\
\text { weight (g) }\end{array}$ & $\begin{array}{c}\text { Yolk } \\
\text { weight (g) }\end{array}$ & $\begin{array}{l}\text { Albumen } \\
\text { weight (g) }\end{array}$ & $\begin{array}{l}\text { Eggshell } \\
\text { weight (g) }\end{array}$ & Yolk (\%) & $\begin{array}{c}\text { Albumen } \\
(\%)\end{array}$ & $\begin{array}{c}\text { Eggshell } \\
(\%)\end{array}$ & $\begin{array}{c}\text { Eggshell } \\
\text { thickness }(\mathrm{mm})\end{array}$ & $\begin{array}{c}\text { Eggshell } \\
\text { strength }(\mathrm{N})\end{array}$ & Egg SI & $\begin{array}{l}\text { Haugh } \\
\text { unit }\end{array}$ & $\begin{array}{l}\text { Yolk } \\
\text { colour }\end{array}$ \\
\hline 2.00 & $58.58^{b}$ & $21 \cdot 24$ & $31.87^{c}$ & 5.48 & $36 \cdot 26^{a}$ & $54.39^{c}$ & $9 \cdot 35$ & 0.316 & 36.88 & $75 \cdot 16$ & $73 \cdot 36^{b}$ & $6 \cdot 29$ \\
\hline 2.75 & $61.08^{\mathrm{a}, \mathrm{b}}$ & 21.02 & $34.38^{\mathrm{b}}$ & 5.68 & $34.40^{\mathrm{b}}$ & $56 \cdot 29^{\mathrm{b}}$ & $9 \cdot 31$ & 0.315 & 37.28 & 73.09 & $73.46^{\mathrm{b}}$ & 6.04 \\
\hline 3.50 & $63.06^{\mathrm{a}}$ & $21 \cdot 12$ & $36 \cdot 21^{\mathrm{a}}$ & $5 \cdot 73$ & $33.59^{b, c}$ & $57 \cdot 35^{\mathrm{b}}$ & 9.06 & 0.311 & $35 \cdot 25$ & 73.31 & $75.98^{\mathrm{a}, \mathrm{b}}$ & 6.32 \\
\hline 4.25 & $64 \cdot 10^{\mathrm{a}}$ & 21.01 & $37.75^{a}$ & $5 \cdot 72$ & $32 \cdot 94^{\mathrm{c}, \mathrm{d}}$ & $58 \cdot 50^{\mathrm{a}}$ & 9.00 & 0.302 & $35 \cdot 27$ & 75.63 & $78 \cdot 36^{\mathrm{a}}$ & $6 \cdot 29$ \\
\hline 5.00 & $64 \cdot 30^{\mathrm{a}}$ & $20 \cdot 68$ & $37 \cdot 77^{\mathrm{a}}$ & $5 \cdot 80$ & $32 \cdot 38^{\mathrm{c}, \mathrm{d}}$ & $58.91^{\mathrm{a}}$ & 9.09 & 0.308 & 34.45 & 73.30 & $78.72^{a}$ & 6.29 \\
\hline 5.75 & $63.76^{\mathrm{a}}$ & $20 \cdot 38$ & $37.67^{\mathrm{a}}$ & $5 \cdot 78$ & $31.93^{\mathrm{d}}$ & $58.99^{\mathrm{a}}$ & 9.07 & 0.311 & 34.94 & 74.72 & $78.45^{\mathrm{a}}$ & 5.88 \\
\hline $\begin{array}{l}\mathrm{SEM} \\
P\end{array}$ & 0.602 & 0.321 & 0.602 & 0.116 & 0.391 & 0.366 & 0.12 & 0.005 & 1.797 & 0.735 & 1.331 & 0.326 \\
\hline Met & 0.003 & 0.209 & $<0.001$ & 0.549 & $<0.001$ & $<0.001$ & 0.345 & 0.318 & 0.858 & 0.096 & 0.023 & 0.499 \\
\hline Linear & $<0.001$ & & $<0.001$ & & $<0.001$ & $<0.001$ & & & & & 0.032 & \\
\hline Quadratic & 0.014 & & 0.001 & & 0.033 & 0.002 & & & & & 0.023 & \\
\hline
\end{tabular}

SI, shape index.

a,b,c,d Mean values within a column with unlike superscript letters were significantly different $(P<0.05)$.

Table 5. Effects of the dietary methionine (Met) level on ovary and oviduct-related indices for duck breeders at 43 weeks of age

(Mean values with their standard errors mean, $n 6$ )

\begin{tabular}{|c|c|c|c|c|c|c|c|c|}
\hline $\begin{array}{l}\text { Dietary Met } \\
(\mathrm{g} / \mathrm{kg})\end{array}$ & LYF number & SYF number & $\begin{array}{l}\text { Oviduct weight } \\
\text { (g/kg BW) }\end{array}$ & $\begin{array}{l}\text { Ovarian weight } \\
(\mathrm{g} / \mathrm{kg} \mathrm{BW})\end{array}$ & $\begin{array}{l}\text { LYF weight } \\
\text { (g) }\end{array}$ & $\begin{array}{l}\text { SYF weight } \\
\text { (g) }\end{array}$ & $\begin{array}{l}\text { LYF weight/ovarian } \\
\text { weight }\end{array}$ & $\begin{array}{c}\text { SYF weight/ovarian } \\
\text { weight }\end{array}$ \\
\hline $2 \cdot 00$ & 5.50 & 9.42 & 36.52 & $39.51^{c}$ & $31.49^{b}$ & 1.71 & $0.74^{\mathrm{b}}$ & 0.04 \\
\hline 2.75 & 5.92 & $10 \cdot 17$ & 35.49 & $40 \cdot 47^{b}$ & $37.02^{a, b}$ & 1.52 & $0.82^{a, b}$ & 0.03 \\
\hline 3.50 & $5 \cdot 83$ & 9.92 & 34.09 & $44 \cdot 61^{\mathrm{a}, \mathrm{b}}$ & $40 \cdot 15^{\mathrm{a}, \mathrm{b}}$ & 1.48 & $0.85^{\mathrm{a}}$ & 0.04 \\
\hline 4.25 & 6.00 & 8.50 & 34.25 & $47 \cdot 79^{\mathrm{a}}$ & $44 \cdot 84^{a}$ & 1.59 & $0.86^{a}$ & 0.04 \\
\hline 5.00 & 5.67 & 9.33 & $37 \cdot 19$ & $48 \cdot 22^{a}$ & $45 \cdot 40^{\mathrm{a}}$ & 1.53 & $0.86^{a}$ & 0.03 \\
\hline $5 \cdot 75$ & $5 \cdot 25$ & 9.58 & 32.25 & $42 \cdot 12^{a, b}$ & $42.51^{\mathrm{a}}$ & 1.39 & $0.85^{a}$ & 0.03 \\
\hline $\begin{array}{l}\text { SEM } \\
P\end{array}$ & 0.223 & 0.301 & 1.305 & $2 \cdot 368$ & $3 \cdot 136$ & 0.285 & 0.032 & 0.007 \\
\hline Met & 0.314 & 0.987 & 0.329 & 0.043 & 0.048 & 0.986 & 0.037 & 0.677 \\
\hline Linear & & & & 0.028 & $<0.001$ & & 0.002 & \\
\hline Quadratic & & & & 0.012 & 0.039 & & 0.138 & \\
\hline
\end{tabular}

LYF, large yellow follicles, follicles with mean diameter $>8 \mathrm{~mm}$; SYF, small yellow follicles, follicles with mean diameter of 3 to $8 \mathrm{~mm}$; BW, body weight.

a,b,c Mean values within a column with unlike superscript letters were significantly different $(P<0.05)$.

ovarian weight $(\mathrm{g} / \mathrm{kg} \mathrm{BW})$ increased in a linear $(P<0.05)$ and quadratic $(P<0.05)$ manner with dietary Met concentration. There were no significant effects $(P>0.05)$ of increasing Met on the number of total SYF and LYF, nor the weight of total SYF and oviduct.

\section{Antioxidative indices and related gene expression in the liver of laying duck breeders}

Table 6 shows that the hepatic content of GSH, and the hepatic activities of GPX and T-AOC increased quadratically $(P<0 \cdot 01)$ 
Table 6. Effects of the dietary methionine (Met) level on antioxidative indices in livers of duck breeders at 43 weeks of age

(Mean values with their standard errors, $n 6$ )

\begin{tabular}{lccccc}
\hline $\begin{array}{l}\text { Dietary } \\
\text { Met (g/kg) }\end{array}$ & $\begin{array}{c}\text { GSH } \\
(\mathrm{mg} / \mathrm{g} \text { prot) }\end{array}$ & $\begin{array}{c}\text { T-SOD } \\
(\mathrm{U} / \mathrm{mg} \text { prot})\end{array}$ & $\begin{array}{c}\text { GPX } \\
(\mathrm{U} / \mathrm{mg} \text { prot})\end{array}$ & $\begin{array}{c}\text { T-AOC } \\
(\mathrm{U} / \mathrm{mg} \text { prot })\end{array}$ & $\begin{array}{c}\text { MDA } \\
(\mathrm{nmol} / \mathrm{mg} \text { prot })\end{array}$ \\
\hline 2.00 & $5.93^{\mathrm{a}, \mathrm{b}}$ & 148.4 & $46.19^{\mathrm{b}}$ & $0.82^{\mathrm{b}}$ & $1.17^{\mathrm{a}}$ \\
2.75 & $7.95^{\mathrm{a}, \mathrm{b}}$ & 140.4 & $55.10^{\mathrm{a}, \mathrm{b}}$ & $1.02^{\mathrm{b}}$ & $1.03^{\mathrm{a}}$ \\
3.50 & $10.13^{\mathrm{a}}$ & 139.4 & $57.66^{\mathrm{a}, \mathrm{b}}$ & $1.95^{\mathrm{a}}$ & $0.89^{\mathrm{a}, \mathrm{b}}$ \\
4.25 & $9.62^{\mathrm{a}, \mathrm{b}}$ & 136.8 & $65.24^{\mathrm{a}}$ & $1.47^{\mathrm{a}, \mathrm{b}}$ & $0.56^{\mathrm{b}}$ \\
5.00 & $5.59^{\mathrm{a}, \mathrm{b}}$ & 138.3 & $51.68^{\mathrm{b}}$ & $1.06^{\mathrm{b}}$ & $1.27^{\mathrm{a}}$ \\
5.75 & $4.77^{\mathrm{b}}$ & 136.7 & $49.58^{\mathrm{b}}$ & $1.06^{\mathrm{b}}$ & $1.31^{\mathrm{a}}$ \\
SEM & 0.550 & 1.715 & 1.546 & 0.098 & 0.091 \\
$P$ & & & & & \\
Met & 0.008 & 0.391 & 0.002 & 0.004 & 0.036 \\
Linear & 0.582 & & 0.592 & 0.629 & 0.610 \\
Quadratic & 0.003 & & $<0.001$ & 0.002 & 0.062 \\
\hline
\end{tabular}

prot, Protein; T-SOD, total superoxide dismutase; GPX, glutathione peroxidase; T-AOC, total antioxidant capacity; MDA, malondialdehyde.

a,b Mean values within a column with unlike superscript letters were significantly different $(P<0.05)$

Table 7. Effects of the dietary methionine (Met) level on the relative hepatic expression of genes related to antioxidation and ovalbumin gene expression in oviduct magnum in duck breeders at 43 weeks of age (Mean values with their standard errors, $n 6$ )

\begin{tabular}{lllllll}
\hline $\begin{array}{l}\text { Dietary Met } \\
\text { (g/kg) }\end{array}$ & $\begin{array}{l}\text { SOD1 } \\
\text { (a.u.) }\end{array}$ & $\begin{array}{l}\text { GPX1 } \\
\text { (a.u.) }\end{array}$ & $\begin{array}{c}C A T \\
\text { (a.u.) }\end{array}$ & $\begin{array}{l}H O-1 \\
\text { (a.u.) }\end{array}$ & $\begin{array}{c}\text { Nrf2 } \\
\text { (a.u. })\end{array}$ & $\begin{array}{l}\text { OVAL } \\
\text { (a.u.) }\end{array}$ \\
\hline 2.00 & 1.01 & $1.04^{\mathrm{c}}$ & $1.03^{\mathrm{a}}$ & $1.03^{\mathrm{b}}$ & $1.01^{\mathrm{b}}$ & $1.01^{\mathrm{b}}$ \\
2.75 & 1.27 & $1.54^{\mathrm{b}, \mathrm{c}}$ & $0.90^{\mathrm{a}}$ & $1.10^{\mathrm{b}}$ & $1.01^{\mathrm{b}}$ & $1.55^{\mathrm{a}, \mathrm{b}}$ \\
3.50 & 1.05 & $2.25^{\mathrm{a}, \mathrm{b}}$ & $0.77^{\mathrm{a}, \mathrm{b}}$ & $1.44^{\mathrm{a}, \mathrm{b}}$ & $1.41^{\mathrm{a}}$ & $1.91^{\mathrm{a}, \mathrm{b}}$ \\
4.25 & 1.16 & $3.43^{\mathrm{a}}$ & $0.75^{\mathrm{a}, \mathrm{b}}$ & $2.15^{\mathrm{a}, \mathrm{b}}$ & $1.48^{\mathrm{a}}$ & $2.38^{\mathrm{a}}$ \\
5.00 & 1.29 & $2.75^{\mathrm{a}, \mathrm{b}}$ & $0.41^{\mathrm{c}}$ & $2.28^{\mathrm{a}}$ & $1.23^{\mathrm{a}, \mathrm{b}}$ & $2.50^{\mathrm{a}}$ \\
5.75 & 1.02 & $1.62^{\mathrm{b}, \mathrm{c}}$ & $0.54^{\mathrm{b}, \mathrm{c}}$ & $1.80^{\mathrm{a}, \mathrm{b}}$ & $0.62^{\mathrm{c}}$ & $2.62^{\mathrm{a}}$ \\
SEM & 0.043 & 0.178 & 0.049 & 0.127 & 0.056 & 0.157 \\
$P$ & & & & & & \\
Met & 0.470 & 0.002 & $<0.001$ & 0.049 & $<0.001$ & 0.045 \\
Linear & & 0.024 & $<0.001$ & 0.001 & 0.267 & $<0.001$ \\
Quadratic & & $<0.001$ & 0.746 & 0.003 & $<0.001$ & $<0.001$ \\
\hline
\end{tabular}

$S O D 1$, superoxide dismutase $1 ; G P X 1$, glutathione peroxidase $1 ; C A T$, catalase; HO-1, haem oxygenase 1; Nrf2, nuclear factor erythroid 2 like 2; OVAL, ovalbumin; a.u., arbitrary units.

a,b,c Mean values within a column with unlike superscript letters were significantly different $(P<0.05)$.

as dietary Met concentration increased; hepatic content of MDA showed reciprocal changes, with only a trend towards a quadratic $(P=0.062)$ effect. Dietary Met levels increased the hepatic expression of GPX1 in a linear $(P<0.05)$ and quadratic $(P<0.001)$ manner in laying duck breeders, and the expression of catalase $(C A T)$ changed linearly $(P<0.001)$ with the Met levels in diet. There was a linear $(P<0 \cdot 01)$ and quadratic $(P<0 \cdot 01)$ effect of dietary Met levels on the hepatic expression of haem oxygenase 1 (HO- 1 ), whereas Nrf2 changed quadratically $(P<0.001)$ with dietary Met levels (Table 7$)$. There were no significant effects $(P>0.05)$ on the plasma contents of GSH or MDA, nor on the activities of T-SOD, GPX or T-AOC (data not shown).

\section{Ovalbumin gene expression in the oviduct magnum of duck breeders}

There was an obvious linear $(P<0.001)$ and quadratic $(P<0.001)$ effect of dietary Met on the relative abundance of OVAL transcripts in the oviduct magnum (Table 7 ).

\section{Antioxidative indices and related genes expression in the liver and brain of hatchlings}

As shown in Table 8, the cerebral but not hepatic activities of T-SOD, GPX and T-AOC in newly hatched ducklings increased quadratically $(P<0 \cdot 01)$ as Met content of the breeders' diet increased; reciprocal quadratic $(P<0.05)$ changes in PC were evident. There were no effects on GSH or MDA contents of either tissue. Dietary Met for the breeders had quadratic $(P<0.05)$ effects on the cerebral expression of GPX1, HO-1 and $N r f 2$ and hepatic expression of $\mathrm{HO}-1$ in the hatchlings (Table 9).

\section{Estimations of the dietary methionine requirements of laying duck breeders}

Results of dietary Met requirements of laying duck breeders as estimated by the quadratic regression analysis are shown in Table 10. The dietary Met requirements for Longyan duck breeders from 19 to 43 weeks of age for optimising egg weight, albumen weight, egg mass, FCR, hatchability, maximal expression of hepatic GPX1 and Nrf2 and its activities were 4.6, 4.9, $4 \cdot 4,4 \cdot 8,4 \cdot 0,4 \cdot 0,4 \cdot 0$ and $4 \cdot 0 \mathrm{~g} / \mathrm{kg}$, respectively.

\section{Discussion}

In this study, dietary Met levels affected the egg weight, egg mass, FCR, hatchability, proportion of healthy ducklings and their weight, but did not affect egg production and fertility. Previously, Xiao et al. ${ }^{(5)}$ found improvements in egg production, FCR, fertility and hatchability after increasing the Met level from 0.25 to $0.35 \%$ in Chinese broiler breeders, whereas Hosseini et al. ${ }^{(8)}$ showed that increasing the Met concentrations from 0.20 to $0.45 \%$ for 8 weeks during the peak laying period in Iranian broiler breeders impaired egg production, egg mass and FCR, but did not affect hatchability, quality of chicks or their weight. In the previous study of Longyan laying ducks from 19 to 47 weeks of age, improvements in egg weight were found after increasing Met level from 0.25 to $0.50 \%$, but egg production, egg mass and FCR were not affected $^{(7)}$. In contrast, in Shaoxing laying ducks, He et al. ${ }^{(6)}$ recorded improved egg production, egg weight, egg mass and FCR from increasing the Met concentration from 0.26 to $0.54 \%$ for 6 weeks during the late laying period. A similar improvement in egg production was obtained after doubling the amount of Met in the basal diets $(0 \cdot 26 \%)$ of Tsaiya laying ducks for 4 weeks ${ }^{(31)}$. Feeding laying hens diets containing $0.26 \%$ Met for 12 weeks starting from 34 weeks of age impaired egg production, egg weight, egg mass and FCR, but adding $0 \cdot 10 \%$ Met normalised these effects ${ }^{(3)}$. In White Leghorn laying hens, Panda et al. ${ }^{(32)}$ showed that egg production, egg weight, egg mass and FCR were not affected by increasing the Met level from 0.30 to $0.42 \%$ in different feed sources for 16 weeks during the peak laying period. Thus, previous studies using different bird ages, strains and/or Met concentrations in the basal diet varied in the responses to increasing dietary levels of Met. The Longyan breed used here is the prevalent duck laying breed in southern China and is of great consequence as more than 80 billion eggs are produced annually. Optimising nutrient provision for the layers and 
Table 8. Effects of the maternal dietary methionine (Met) level of duck breeders at 38 weeks of age on antioxidant indices in the liver and brain of hatchlings (Mean values with their pooled standard errors, $n 6$ )

\begin{tabular}{|c|c|c|c|c|c|c|c|c|c|c|c|}
\hline \multirow[b]{2}{*}{$\begin{array}{l}\text { Dietary } \\
\text { Met }(\mathrm{g} / \mathrm{kg})\end{array}$} & \multicolumn{5}{|c|}{ Liver } & \multicolumn{5}{|c|}{ Brain } & \multirow[b]{2}{*}{$\begin{array}{c}\mathrm{PC} \\
\text { (nmol/mg prot) }\end{array}$} \\
\hline & $\begin{array}{c}\text { GSH } \\
\text { (mg/g prot) }\end{array}$ & $\begin{array}{c}\text { T-SOD } \\
\text { (U/mg prot) }\end{array}$ & $\begin{array}{c}\text { GPX } \\
\text { (U/mg prot) }\end{array}$ & $\begin{array}{c}\text { T-AOC } \\
\text { (U/mg prot) }\end{array}$ & $\begin{array}{c}\text { MDA } \\
\text { (nmol/mg prot) }\end{array}$ & $\begin{array}{c}\text { GSH } \\
\text { (mg/g prot) }\end{array}$ & $\begin{array}{c}\text { T-SOD } \\
\text { (U/mg prot) }\end{array}$ & $\begin{array}{c}\text { GPX } \\
\text { (U/mg prot) }\end{array}$ & $\begin{array}{c}\text { T-AOC } \\
\text { (U/mg prot) }\end{array}$ & $\begin{array}{c}\text { MDA } \\
\text { (nmol/mg prot) }\end{array}$ & \\
\hline 2.00 & 7.06 & 553.3 & 74.4 & 1.13 & 0.31 & 3.03 & $93 \cdot 0^{a, b}$ & $21 \cdot 4^{\mathrm{a}, \mathrm{b}}$ & $0.41^{b}$ & 7.64 & $7.44^{\mathrm{a}}$ \\
\hline 2.75 & 6.39 & 537.7 & 73.8 & 1.17 & 0.21 & 3.15 & $99 \cdot 6^{a, b}$ & $20 \cdot 6^{\mathrm{a}, \mathrm{b}}$ & $0.46^{\mathrm{a}, \mathrm{b}}$ & 8.28 & $6 \cdot 55^{\mathrm{a}, \mathrm{b}}$ \\
\hline 3.50 & 6.51 & 493.8 & 60.2 & 1.24 & 0.24 & 3.22 & $107 \cdot 6^{a}$ & $24 \cdot 0^{\mathrm{a}}$ & $0.50^{\mathrm{a}, \mathrm{b}}$ & 8.72 & $6 \cdot 39^{a, b}$ \\
\hline 4.25 & 6.54 & 557.2 & 60.6 & 1.19 & 0.29 & 3.27 & $104 \cdot 0^{\mathrm{a}}$ & $24 \cdot 5^{\mathrm{a}}$ & $0.61^{\mathrm{a}}$ & 8.26 & $4.72^{\mathrm{b}}$ \\
\hline 5.00 & 5.52 & 549.4 & 63.7 & 1.21 & 0.28 & $2 \cdot 88$ & $93 \cdot 6^{\mathrm{a}, \mathrm{b}}$ & $19.7^{\mathrm{b}}$ & $0.58^{\mathrm{a}}$ & 7.90 & $6 \cdot 60^{\mathrm{a}, \mathrm{b}}$ \\
\hline 5.75 & 5.52 & 523.8 & $62 \cdot 1$ & 1.25 & 0.31 & 2.79 & $85 \cdot 8^{\mathrm{b}}$ & $19.6^{\mathrm{b}}$ & $0.56^{\mathrm{a}, \mathrm{b}}$ & 8.51 & $6 \cdot 55^{\mathrm{a}, \mathrm{b}}$ \\
\hline $\begin{array}{l}\text { SEM } \\
P\end{array}$ & 0.233 & 7.708 & 1.612 & 0.023 & 0.017 & 0.056 & 2.024 & 0.507 & 0.019 & 0.192 & 0.270 \\
\hline $\begin{array}{l}\text { Met } \\
\text { Linear } \\
\text { Quadratic }\end{array}$ & 0.541 & 0.287 & 0.060 & 0.662 & 0.682 & 0.212 & $\begin{array}{l}0.004 \\
0.189 \\
0.008\end{array}$ & $\begin{array}{l}0.029 \\
0.204 \\
0.005\end{array}$ & $\begin{array}{l}0.032 \\
0.982 \\
0.004\end{array}$ & 0.098 & $\begin{array}{l}0.041 \\
0.241 \\
0.031\end{array}$ \\
\hline
\end{tabular}

prot, Protein; T-SOD, total superoxide dismutase; GPX, glutathione peroxidase; T-AOC, total antioxidant capacity; MDA, malondialdehyde; PC, protein carbonyl.

a,b Mean values within a column with unlike superscript letters were significantly different $(P<0.05)$.

Table 9. Effects of the maternal dietary methionine (Met) level of duck breeders at 38 weeks of age on the relative hepatic and cerebral expression levels of genes related to antioxidation in hatchlings

(Mean values with their pooled standard errors, $n 6$ )

\begin{tabular}{|c|c|c|c|c|c|c|c|c|c|c|}
\hline \multirow[b]{2}{*}{ Dietary Met $(\mathrm{g} / \mathrm{kg})$} & \multicolumn{5}{|c|}{ Liver } & \multicolumn{5}{|c|}{ Brain } \\
\hline & SOD1 (a.u.) & GPX1 (a.u.) & $C A T$ (a.u.) & $\mathrm{HO}-1$ (a.u.) & Nrf2 (a.u.) & SOD1 (а.u.) & GPX1 (a.u.) & CAT (a.u.) & HO-1 (a.u.) & Nrf2 (a.u.) \\
\hline 2.00 & 1.05 & 1.05 & 1.01 & $0.98^{\mathrm{b}}$ & 1.01 & 1.02 & $1.00^{\mathrm{a}, \mathrm{b}}$ & 1.00 & $1.01^{b}$ & $1.00^{b}$ \\
\hline 2.75 & 0.93 & 0.99 & 1.14 & $1.54^{\mathrm{a}}$ & 1.08 & 1.00 & $1.34^{\mathrm{a}}$ & 0.80 & $0.93^{\mathrm{b}}$ & $0.97^{\mathrm{b}}$ \\
\hline 3.50 & 0.99 & 1.13 & 1.24 & $1.57^{\mathrm{a}}$ & 1.13 & $1 \cdot 18$ & $1.44^{\mathrm{a}}$ & 1.04 & $1.43^{\mathrm{a}, \mathrm{b}}$ & $1.05^{\mathrm{b}}$ \\
\hline 4.25 & 1.05 & 1.26 & 1.18 & $1.63^{\mathrm{a}}$ & 1.36 & 1.03 & $1.35^{\mathrm{a}}$ & 1.03 & $1.71^{\mathrm{a}}$ & $1.44^{\mathrm{a}}$ \\
\hline 5.00 & 1.23 & $1 \cdot 13$ & 1.16 & $1.48^{\mathrm{a}}$ & 1.24 & 0.93 & $1.34^{\mathrm{a}}$ & 0.85 & $1.52^{\mathrm{a}, \mathrm{b}}$ & $1.21^{a, b}$ \\
\hline $5 \cdot 75$ & 0.91 & 1.00 & 0.91 & $0.92^{\mathrm{b}}$ & 0.99 & 0.92 & $0.94^{\mathrm{b}}$ & $1 \cdot 13$ & $1.42^{\mathrm{a}, \mathrm{b}}$ & $1.02^{\mathrm{b}}$ \\
\hline SEM & 0.065 & 0.079 & 0.033 & 0.068 & 0.050 & 0.039 & 0.052 & 0.033 & 0.076 & 0.064 \\
\hline \multicolumn{11}{|l|}{$P$} \\
\hline Met & 0.387 & 0.073 & 0.441 & 0.004 & 0.065 & 0.737 & 0.033 & 0.266 & $<0.001$ & 0.042 \\
\hline Linear & & & & 0.725 & & & 0.445 & & 0.175 & 0.139 \\
\hline Quadratic & & & & $<0.001$ & & & $<0.001$ & & $<0.001$ & 0.034 \\
\hline
\end{tabular}

SOD1, superoxide dismutase 1; GPX1, glutathione peroxidase 1; CAT, catalase; HO-1, haem oxygenase 1; Nrf2, nuclear factor erythroid 2 like 2; a.u., arbitrary units. ${ }^{a, b}$ Mean values within a column with unlike superscript letters were significantly different $(P<0.05)$.

Table 10. Estimations of the dietary methionine (Met) requirements based on quadratic regressions of egg weight, albumen weight, egg mass and hatchability, glutathione peroxidase 1 (GPX1), nuclear factor erythroid 2 like 2 (Nrf2) mRNA and GPX activity on dietary Met concentrations

\begin{tabular}{llccc}
\hline Dependent variables & Regression equation* & $R^{2}$ & $P$ & $\begin{array}{c}\text { Dietary Met } \\
\text { requirement }(\mathrm{g} / \mathrm{kg}) \dagger\end{array}$ \\
\hline Egg weight & $Y=53.005+4.613 X-0.481 X^{2}$ & 0.966 & 0.032 & 4.6 \\
Albumen weight & $Y=28.507+3.687 X-0.361 X^{2}$ & 0.995 & 0.001 & 4.9 \\
Egg mass & $Y=42.263+4.603 X-0.502 X^{2}$ & 0.989 & 0.043 & 4.4 \\
Feed conversion ratio & $Y=4.163-0.343 X+0.034 X^{2}$ & 0.869 & 0.042 & 4.8 \\
Hatchability & $Y=56.967+14.421 X-1.722 X^{2}$ & 0.999 & 0.013 & 4.0 \\
Hepatic activity of GPX & $Y=1.383+31.195 X-3.704 X^{2}$ & 0.764 & $<0.001$ & 4.0 \\
Hepatic expression of GPX1 & $Y=-4.855+3.667 X-0.435 X^{2}$ & 0.795 & $<0.001$ & 4.0 \\
Hepatic expression of Nif2 & $Y=-0.763+1.263 X-0.150 X^{2}$ & 0.883 & $<0.001$ & 4.0 \\
\hline
\end{tabular}

* $Y$ is the dependent variable and $X$ is the dietary Met concentration $(\mathrm{g} / \mathrm{kg})$.

$\dagger$ Dietary Met requirement $=$ the optimal dietary Met concentration $(\mathrm{g} / \mathrm{kg})$.

breeders is of economic importance, so the present findings are commercially relevant.

Albumen weight, albumen proportion and Haugh unit increased significantly, and the yolk proportion decreased with increasing dietary Met in the present study; other indices of egg quality were unchanged. In Longyan laying ducks, egg SI, Haugh unit, yolk colour, yolk weight and eggshell weight did not change but the albumen weight increased, and thickness, 
relative weight and strength of eggshell decreased by increasing dietary Met from 0.25 to $0.50 \%{ }^{(7)}$. In Shaoxing laying ducks, the Haugh unit and yolk colour were not affected, but the albumen height and eggshell thickness increased after the Met levels changed from 0.26 to $0.54 \%^{(6)}$. Supplementing the diets of laying hens with various formulations of Met had inconsistent effects on the egg quality traits that were affected in the present study with Longyan breeders ${ }^{(3,20,32)}$. In the current study, increasing dietary Met led to linear increases in the albumen weight, together explaining the increase in egg weight and likely accounting for the weight of hatchlings ${ }^{(33)}$.

Albumen (egg white) consists mainly (54\%) of the major protein $\mathrm{OVAL}^{(33)}$, lysozyme and ovotransferrin proteins. The expression of $O V A L$ mRNA in the oviduct magnum (the main location for albumen secretion) increased linearly and quadratically as the Met concentration increased. To the best of our knowledge, this is the first report of enhanced expression of OVAL mRNA owing to increasing dietary Met in any avian species. In laying ducks, dietary Met supplementation increased the plasma levels of Met, lysine, arginine, isoleucine and histidine ${ }^{(6)}$, all of which are essential components of OVAL ${ }^{(34)}$, which may explain why dietary Met enhanced the mRNA expression level of $O V A L$ here. This finding may explain why increasing the Met level increased the albumen weight and hatchling weight because albumen has multiple physiological functions during different phases of embryo development ${ }^{(35)}$. Exactly the same reasoning could explain the lowered hatchability of eggs from duck breeders fed low dietary Met ( 2.00 or $2.75 \mathrm{~g} / \mathrm{kg}$ ).

Ovarian-related indices ${ }^{(36)}$ were measured to evaluate the effects of Met on development of the reproductive system. Dietary Met influences secretion of follicle-stimulating hormone and luteinising hormone, which stimulate the growth and development of follicles ${ }^{(4)}$. The weight of total LYF and the fraction of ovarian weight they accounted for were the only variables affected by dietary Met fed to the breeder ducks. The present results were consistent with the basal diet, with $2.00 \mathrm{~g} / \mathrm{kg}$, being deficient in Met for breeder ducks. Metdeficient diets in laying hens depressed protein synthesis in the liver (one function being to produce and export egg yolk proteins), magnum and other segments of the oviduct ${ }^{(37)}$. Other effects of Met deficiency include a decrease in breast meat yield in broilers ${ }^{(9)}$ and influences on expression of genes related to protein turnover ${ }^{(11)}$.

In the present study, dietary Met supplementation enhanced the hepatic levels of GSH, and activities of GPX and T-AOC, as well as the expression of $\mathrm{HO}$-1and $\mathrm{Nrf} 2$ genes in laying duck breeders. Supplemental Met reduced levels of MDA with a trend towards a quadratic effect, while not changing T-SOD activity or SOD1 gene expression. The transcription factor $N r f 2$ plays a crucial role in maintaining stable liver functioning by regulating the expression of antioxidants (GPX, HO-1, CAT and $S O D)^{(38,39)}$. The $H O-1$ has a crucial role in generating biliverdin and bilirubin, which are involved in the antioxidant defence system, and nutritional factors modulate $N r f 2$ in order to increase antioxidant defences ${ }^{(40,41)}$. One previous study in young grass carp fish ${ }^{(42)}$ investigated whether an adequate level of Met improved the antioxidant status by upregulating the expression of $N r f 2$ mRNA. Our previous study in Longyan laying ducks showed that increasing dietary Met from the 2.5 to $5.5 \mathrm{~g} / \mathrm{kg}$ did not affect GSH, GPX or MDA in plasma ${ }^{(7)}$. In 16-week-old turkey hens, increasing Met from the levels recommended $^{(43)}$ had no effect on MDA, GPX and SOD activity in plasma or breast muscles, but hepatic levels of SOD and GSH declined and MDA increased significantly ${ }^{(44,45)}$. There are numerous studies in various avian species and types ${ }^{(22,46-50)}$ on effects of dietary Met at below and above recommended levels on antioxidant indices in laying duck breeders. As noted earlier, inconsistencies in results and differences to what has been observed here mainly reflect the differences in the animal models, Met deficiency level and tissue selected for evaluating the antioxidant status. In addition to the effects of graded dietary Met on the antioxidant status of breeders, and the effects measured on their eggs, some 'carryover' effects were obvious on the hatchlings in the present study. For the most part, these were noted in brain rather than liver and included brain carbonylated protein. The effects of maternal dietary Met on the antioxidant variables measured in hatchlings did not exactly follow the effects noted earlier on maternal traits, nor the hatchability and proportion of healthy ducklings. Previous studies have investigated the effects of dietary Met on breeders, but they generally did not consider its effects on their offspring ${ }^{(5,8)}$. Indeed, only Brun et $a l .{ }^{(51)}$ showed that maternal dietary Met affects the growth performance and lipid metabolism in the offspring of Muscovy duck breeders. Similarly, in sows fed a diet supplemented with Met in the form of DL-2-hydroxy-4-methylthiobutanoic acid, reductions in oxidative stress occurred in the intestines of their piglets ${ }^{(52)}$

The laying performance and reproductive performance of duck breeders are mainly concerns in duck industry. In the current study, the dietary Met levels for maximising the egg weight, albumen weight, egg mass and FCR were 4.6, 4.9, 4.4 and $4.8 \mathrm{~g} / \mathrm{kg}$, respectively. In addition, diet containing $4.0 \mathrm{~g}$ Met/kg could attain optimal hatchability, hepatic GPX1 and Nrf2 expression, and the hepatic GPX activity in duck breeders. These results indicate that dietary Met level at $4 \cdot 0-5 \cdot 0 \mathrm{~g} / \mathrm{feed}$ is necessary in laying duck breeders. Previous studies used quadratic regression models as a fitted model with lower $P$ values and higher $R^{2}$ values to evaluate nutritional requirements of poultry ${ }^{(53)}$. Thus, the albumen weight and Nrf2 mRNA expression level are supposed to be more reliable indicators for the evaluation of Met requirements of laying duck breeders.

In conclusion, the present study showed that the egg weight, albumen weight, egg mass, FCR, hatchability and 1-d duckling BW of laying ducks breeders were improved by increasing dietary Met to approximately $4 \cdot 0-5 \cdot 0 \mathrm{~g} / \mathrm{kg}$. The increases in the egg weight and albumen weight may have reflected up-regulated expression of $O V A L$ in the oviduct magnum of breeders by increasing dietary Met. A diet containing $4.0 \mathrm{~g}$ Met/kg would achieve optimal hepatic GPX1 and Nrf2 expression, maximise the activity of GPX and minimise lipid peroxidation. There was an obvious carryover effect to the embryos as the maternal dietary Met enhanced $\mathrm{HO}-1$ and $\mathrm{Nrf} 2$ transcripts and antioxidant status, and reduced carbonylated protein in the brain of hatchlings. 


\section{Acknowledgements}

The authors sincerely thank W. Bruce Currie (Emeritus Professor, Cornell University, Ithaca, NY) for his help in presentation of this manuscript.

This study was supported by the Earmarked Fund for Modern Agri-industry Technology Research System (grant no. CARS-42-13), Supporting Program for the Research of State Key Laboratory of Livestock and Poultry Breeding, Science \& Technology Program of Guangdong Province (grant no. 2013A061401020), Operating Funds for Guangdong Provincial Key Laboratory of Animal Breeding and Nutrition (grant no. 2014B030301054), Supporting Program for Guangdong Agricultural Research \& Development Center of Livestock and Poultry Healthy Breeding, and President Foundation of Guangdong Academy of Agricultural Sciences (grant no. 201619).

The authors' contributions are as follows: D. R., A. M. F., L. Y. and C. Z. were responsible for the study design; D. R. conducted the animal trial, performed the sample analyses and prepared the manuscript; C. Z. and A. M. F. participated in editing of the manuscript; Q. F., C. L. and Y. W. contributed to the sample analyses. W. X., S. W. and W. C. assisted with the duck trial. All authors read and approved the final manuscript.

None of the authors has any conflicts of interest to declare.

\section{References}

1. Bunchasak C (2009) Role of dietary methionine in poultry production. J Poult Sci 46, 169-179.

2. Carew LB, McMurtry JP \& Alster FA (2003) Effects of methionine deficiencies on plasma levels of thyroid hormones, insulin-like growth factors-I and-II, liver and body weights, and feed intake in growing chickens. Poult Sci 82, 1932-1938.

3. Bunchasak C, Ratchadapornvanitch Y \& Thiengtham J (2012) Comparative effects of supplemental DL-2-hydroxy-4[methylthio] butanoic acid and DL-methionine in diet on egg production and quality in laying hens. J Poult Sci 49, 260-267.

4. Meng GH, Song D, Li LB, et al. (2017) Dietary methionine requirement of Jing Brown layer hens from 9 to 17 weeks of age. J Anim Physiol Anim Nutr 101, 925-935.

5. Xiao X, Wang Y, Liu W, et al. (2017) Effects of different methionine sources on production and reproduction performance, egg quality and serum biochemical indices of broiler breeders. Asian-Austral J Anim Sci 30, 828-833.

6. He JH, Li JB, Gao FX, et al. (2003) Dietary methionine requirement of the Chinese egg-laying duck. Br Poult Sci $\mathbf{4 4}$, 741-745.

7. Fouad AM, Ruan D, Lin YC, et al. (2016) Effects of dietary methionine on performance, egg quality and glutathione redox system in egg-laying ducks. Br Poult Sci 57, 818-823.

8. Hosseini SA, Zaghari M, Lotfollahian H, et al. (2012) Reevaluation of methionine requirement based on performance and immune responses in broiler breeder hens. J Poult Sci 49, 26-33.

9. Barnes DM, Calvert CC \& Klasing KC (1995) Methionine deficiency decreases protein accretion and synthesis but not tRNA acylation in muscles of chicks. $J$ Nutr 125, 2623-2630.

10. Corzo A, Kidd MT, Dozier WA, et al. (2006) Protein expression of pectoralis major muscle in chickens in response to dietary methionine status. BrJ Nutr 95, 703-708.

11. Del Vesco AP, Gasparino E, Grieser DO, et al. (2015) Effects of methionine supplementation on the expression of protein deposition-related genes in acute heat stress-exposed broilers. PLOS ONE 10, e0115821.
12. Fouad AM \& El-Senousey HK (2014) Nutritional factors affecting abdominal fat deposition in poultry: a review. Asian-Austral J Anim Sci 27, 1057.

13. Kikusato M, Sudo S \& Toyomizu M (2015) Methionine deficiency leads to hepatic fat accretion via impairment of fatty acid import by carnitine palmitoyltransferase I. Br Poult Sci 56, 225-231.

14. Yin J, Ren W, Yang G, et al. (2016) L-cysteine metabolism and its nutritional implications. Mol Nutr Food Res 60, 134-146.

15. Lee S, Han K, Nakamura Y, et al. (2013) Dietary L-cysteine improves the antioxidative potential and lipid metabolism in rats fed a normal diet. Biosci Biotechnol Biochem 77, $1430-1434$

16. Huang CX, Wang B, Min Z, et al. (2014) Dietary inclusion level and time effects of taurine on broiler performance, meat quality, oxidative status and muscle taurine content. Br Poult Sci 55, 598-604.

17. Jia R, Bao YH, Zhang Y, et al. (2014) Effects of dietary $\alpha$-lipoic acid, acetyl-1-carnitine, and sex on antioxidative ability, energy, and lipid metabolism in broilers. Poult Sci 93, 2809-2817.

18. Vesco AP, Gasparino E, Grieser DO, et al. (2015b) Effects of methionine supplementation on the expression of oxidative stress-related genes in acute heat stress-exposed broilers. $\mathrm{Br} \mathrm{J}$ Nutr 113, 549-559.

19. Yang GL, Zhang KY, Ding XM, et al. (2016) Effects of dietary DL-2-hydroxy-4 (methylthio) butanoic acid supplementation on growth performance, indices of ascites syndrome, and antioxidant capacity of broilers reared at low ambient temperature. Int J Biometeorol 60, 1193-1203.

20. Liu Y, Lin X, Zhou X, et al. (2017) Effects of dynamic feeding low and high methionine diets on egg quality traits in laying hens. Poult Sci 96, 1459-1465.

21. Zeng QF, Zhang Q, Chen X, et al. (2015) Effect of dietary methionine content on growth performance, carcass traits, and feather growth of Pekin duck from 15 to 35 days of age. Poult Sci 94, 1592-1599.

22. Gvaryahu G, Robinzon B, Meltzer A, et al. (1984) Artificial insemination and natural mating in the crossbreeding of the Muscovy drake and the Pekin duck. Poult Sci 63, 386-387.

23. Zhao JP, Zhang Q, Jiao HC, et al. (2016) Ovalbumin expression in the oviduct magnum of hens is related to the rate of egg laying and shows distinct stress-type-specific responses. J Anim Physiol Anim Nutr 100, 876-883.

24. Xia WG, Fouad AM, Chen W, et al. (2017) Estimation of dietary arginine requirements for Longyan laying ducks. Poult Sci 96, 144-150.

25. Tsunekage T \& Ricklefs RE (2015) Increased lipid peroxidation occurs during development in Japanese quail (Coturnix japonica) embryos. Br Poult Sci 56, 262-266.

26. Tona K, Onagbesan O, De Ketelaere B, et al. (2004) Effects of age of broiler breeders and egg storage on egg quality, hatchability, chick quality, chick weight, and chick posthatch growth to forty-two days. J Appl Poult Res 13, 10-18.

27. Huang C, Jiao H, Song Z, et al. (2015) Heat stress impairs mitochondria functions and induces oxidative injury in broiler chickens. J Anim Sci 93, 2144-2153.

28. Livak KJ \& Schmittgen TD (2001) Analysis of relative gene expression data using real-time quantitative PCR and the $2^{-\Delta \Delta \mathrm{CT}}$ method. Methods 25, 402-408.

29. Dozier WA, Corzo A, Kidd MT, et al. (2009) Digestible lysine requirements of male and female broilers from fourteen to twenty-eight days of age. Poult Sci 88, 1676-1682.

30. Desu MM \& Raghavarao D (1990) Sample Size Methodology. New York, NY: Academic Press, Inc.

31. Lien TF \& Jan DF (1999) The effect on the lipid metabolism of Tsaiya ducks when high levels of choline or methionine 
are added to the duck's diet. Asian-Austral J Anim Sci $\mathbf{1 2}$ 1090-1095.

32. Panda AK, Rao SR, Raju MVLN \& Bhanja SK (2007) Relative performance and immune response in white leghorn layers fed liquid DL-methionine hydroxy analogue and DL-methionine. Asian-Austral J Anim Sci 20, 948.

33. Williams KC (1992) Some factors affecting albumen quality with particular reference to Haugh unit score. World's Poult Sci J 48, 5-16.

34. Smith MB \& Back JF (1970) Studies on ovalbumin V. The amino acid composition and some properties of chicken, duck, and turkey ovalbumins. Austral J Bio Sci 23, 1221-1228.

35. Moran ET (2007) Nutrition of the developing embryo and hatchling. Poult Sci 86, 1043-1049.

36. Fouad AM, Chen W, Ruan D, et al. (2017) Effects of dietary lysine supplementation on performance, egg quality, and development of reproductive system in egg-laying ducks. J Appl Anim Res (Epublication ahead of print version 3 April 2017).

37. Hiramoto K, Muramatsu T \& Okumura J (1990) Effect of methionine and lysine deficiencies on protein synthesis in the liver and oviduct and in the whole body of laying hens. Poult Sci 69, 84-89.

38. Li W \& Kong AN (2009) Molecular mechanisms of Nrf2-mediated antioxidant response. Mol Carcinog 48, 91-104.

39. Lee MT, Lin WC, Yu B, et al. (2017) Antioxidant capacity of phytochemicals and their potential effects on oxidative status in animals - a review. Asian-Austral J Anim Sci 30, 299-308.

40. Ryter SW, Alam J \& Choi AM (2006) Heme oxygenase-1/ carbon monoxide: from basic science to therapeutic applications. Physiol Rev 86, 583-650.

41. Alam J \& Cook JL (2003) Transcriptional regulation of the heme oxygenase-1 gene via the stress response element pathway. Curr Pharm Des 9, 2499-2511.

42. Pan FY, Wu P, Feng L, et al. (2017) Methionine hydroxyl analogue improves intestinal immunological and physical barrier function in young grass carp (Ctenopharyngodon idella). Fish Shellfish Immunol 64, 122-136.
43. National Research Council (1994) Nutrient Requirements of Poultry. 9th ed. Washington, DC: National Academies Press.

44. Jankowski J, Kubińska M, Juśkiewicz J, et al. (2016) The effect of dietary methionine levels on several parameters of fattening turkeys. Arch Anim Nutr 70, 120-140.

45. Jankowski J, Kubińska M, Juśkiewicz J, et al. (2017) Effect of different dietary methionine levels on the growth performance and tissue redox parameters of turkeys. Poult Sci 96, 1235-1243.

46. Park I, Pasquetti TJ, Malheiros RD, et al. (2016) Effects of feed grade L-methionine on intestinal redox status, intestinal development, and growth performance of turkey poults compared with conventional DL-methionine. J Anim Sci 94 , 93-93.

47. Vesco AP, Gasparino E, Grieser DO, et al. (2014) Effects of methionine supplementation on the redox state of acute heat stress-exposed quails. J Anim Sci 92, 806-815.

48. Shen YB, Ferket P, Park I, et al. (2015) Effects of feed grademethionine on intestinal redox status, intestinal development, and growth performance of young chickens compared with conventional-methionine. J Anim Sci 93, 2977-2986.

49. Wen C, Jiang XY, Ding LR, et al. (2017) Effects of dietary methionine on growth performance, meat quality and oxidative status of breast muscle in fast-and slow-growing broilers. Poult Sci 96, 1707-1714.

50. Chen YP, Chen X, Zhang H, et al. (2013) Effects of dietary concentrations of methionine on growth performance and oxidative status of broiler chickens with different hatching weight. Br Poult Sci 54, 531-537.

51. Brun JM, Bernadet MD, Cornuez A, et al. (2015) Influence of grand-mother diet on offspring performances through the male line in Muscovy duck. BMC Genet 16, 145.

52. Zhong HJ, Li H, Liu GM, et al. (2016) Increased maternal consumption of methionine as its hydroxylanalog promoted neonatal intestinal growth without compromising maternal energy homeostasis. J Anim Sci Biotechnol 7, 46.

53. Lu L, Chang B, Liao XD, et al. (2016) Use of molecular biomarkers to estimate manganese requirements for broiler chickens from 22 to 42 d of age. Br J Nutr 116, 1512-1518. 